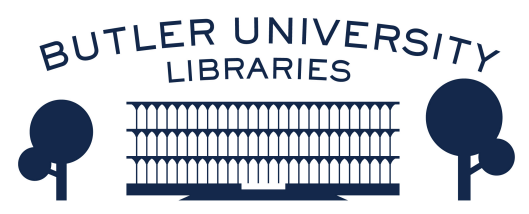

Butler University

Digital Commons @ Butler University

Spring 1-2020

\title{
Indiana Social-Emotional Learning Competencies: A Neurodevelopmental, Culturally Responsive Framework
}

Brandie M. Oliver

Christy T. Berger

Follow this and additional works at: https://digitalcommons.butler.edu/coe_papers

Part of the Student Counseling and Personnel Services Commons 
Indiana Social-Emotional Learning Competencies: A Neurodevelopmental

Culturally Responsive Framework

Brandie M. Oliver

Butler University

Christy T. Berger

Indiana Department of Education

Brandie M. Oliver, College of Education, Butler University; Christy T. Berger, Director of Social, Emotional, and Behavioral Wellness, Indiana Department of Education.

This work was supported in part by the Title IV Part A Student Support and Academic Achievement Grant.

Correspondence concerning this article should be addressed to: Brandie Oliver, Butler University, College of Education, 4600 Sunset Avenue, Indianapolis, IN, 46208. Email: bmoliver@butler.edu 


\begin{abstract}
Social-emotional learning (SEL) programs and practices have gained momentum across the state of Indiana within recent years in response to the changing needs of student and families. In many school communities, SEL has been adopted due to the heightened challenges posed by students impacted by trauma or chronic stress. As schools began to adopt SEL programs and practices, the Indiana Department of Education responded by developing the Indiana Social-Emotional Learning Competencies to provide a unified framework and to provide several resources with which educators in the state continue to evolve their work. This article outlined foundational principles of SEL, highlighted unique aspects of the Indiana SEL competencies, and presented implications of the role of the school counselor in working toward systemic implementation of SEL.
\end{abstract}

Keywords: social-emotional learning, educational neuroscience, trauma, school counseling 
Indiana Social-Emotional Learning Competencies: A Neurodevelopmental

Culturally Responsive Framework

Educating students can no longer be focused solely on developing academic knowledge and content; critical research has revealed social, emotional, and cognitive capabilities are integral to, and inseparable with, students' academic and postsecondary success (Jones \& Khan, 2017). The support for social-emotional learning (SEL) is robust. Scholarship pertaining to both research and practice has had rapid growth and interest over the last two decades (Durlak, Domitrovich, Weissberg, \& Gullotta, 2015; Humphrey, 2013). Due both to SEL's fast-paced spread into education and how SEL integrates multiple disciplines, a common challenge has been to identify one universal framework (Berg, Nolan, Yoder, Osher, \& Mart, 2019; Blyth, 2018). According to the 2018 American Institutes for Research (AIR) Report, 136 SEL frameworks from 14 different schools of thought (i.e., human development, psychology, education, etc.) have been identified (Berg et al., 2019; Berg, Osher, Same, Nolan, Benson, \& Jacobs, 2017). Exploring the number of different SEL frameworks presents a daunting task for educators. It poses various challenges for educators when trying to identify which ones are being implemented or in current use, as well as discovering the key features when working toward a universal framework to guide the future of SEL (Jones \& Kahn, 2017; Berg et al., 2019; Blyth, 2018). In order to address these challenges, Indiana developed a comprehensive, neurodevelopmental, culturally responsive SEL framework with developmentally appropriate student competencies spanning grades PK-12. Throughout this work, several questions were explored to guide the development of the comprehensive SEL framework and competencies. This article selected these three key questions that helped map Indiana's SEL work. What is the 
foundation of SEL? What makes the Indiana SEL competencies unique? What role will the school counselor play in the comprehensive and systemic implementation of SEL?

\section{Foundations of Social-Emotional Learning}

Social-emotional learning development is an integral component enabling students to build relationships with others, cope with stress, problem-solve, acquire mental, emotional, and academic supports, and succeed in work and life (Osher, Kidron, Brackett, Dymnicki, Jones, \& Weissberg, 2016). Research supports that "effective mastery of social-emotional competencies is associated with greater well-being and better school performance whereas the failure to achieve competence in these areas can lead to a variety of personal, social, and academic difficulties" (Durlak, Weissberg, Dymnicki, Taylor, \& Schellinger, 2011, p. 406). What is the need for social-emotional learning in education? In simple terms, it is to prepare all students to be equipped to manage the inevitable challenges, stress, and uncertainties that often arise in everyday life as well as to attain personal and postsecondary success. The Collaborative for Academic, Social, and Emotional Learning (CASEL) defines SEL as the process through which students gain and effectively apply the knowledge, attitudes, and skills necessary to understand and manage emotions, set and achieve positive goals, feel and express empathy for others, develop and maintain positive relationships, and make responsible decisions (Collaborative for Academic, Social, and Emotional Learning (CASEL), 2018).

CASEL has been a leader, a catalyst, an advocate, and a collaborator while serving the field of Social and Emotional Learning. CASEL describes SEL (CASEL, 2018) as a process through which children and adults can identify and regulate emotions, work toward positive goals, demonstrate empathy for others, develop healthy relationships, and can apply a decisionmaking model. CASEL's SEL framework has been widely used by researchers, policymakers, 
and educators to help guide, design, and implement social-emotional learning within PK-12 schools across the nation (Weissberg, Durlak, Domitrovich, \& Gullotta, 2015). Borowski (2019) described CASEL's framework for Systemic Social and Emotional Learning as an integrated framework that works to promote its five SEL competencies through multiple contexts within the school environment.

CASEL developed five core intrapersonal, interpersonal and, cognitive competencies aimed to foster the development of the cognitive, affective, and behavioral domains of social-emotional learning (CASEL, 2013).

A brief description of CASEL's five core competencies is listed below.

1. Self-Awareness: Recognizing feelings as they occur; having a realistic assessment of one's own abilities and a well-grounded sense of self-confidence

2. Social Awareness: Sensing what others are feeling; being able to take their perspective; appreciating and interacting positively with diverse groups.

3. Self-Management: Handling emotions so they facilitate rather than interfere with the task a hand; delaying gratification to pursue goals; persevering in the face of setbacks.

4. Relationship Skills: Handling emotions in relationships effectively; establishing and maintaining healthy and rewarding relationships based on cooperation; negotiating solutions to conflict; seeking help when needed.

5. Responsible Decision Making: Accurately assessing risks; making decisions based on a consideration of all relevant factors and the likely consequences of alternative courses of actions; respecting others; taking personal responsibility for one's decisions. 
By using a structured SEL framework, as the one CASEL has provided, schools can follow a detailed roadmap through which educators can work to nurture and develop SEL competencies in all students.

\section{Key Benefits of Social-Emotional Learning}

Numerous studies have revealed compelling research to detail multiple key benefits of social-emotional learning. SEL has shown a positive impact on student achievement and an increase in pro-social skill development. The initial meta-analysis conducted by Durlak, Weissberg, Dymnicki, Taylor, and Schellinger (2011) revealed students that participated in SEL showed a positive impact on academics, resulting in an 11-percentile point gain in achievement and an increased development of social-emotional skills, improved attitude toward self and others, improved positive social behaviors, and decreased conduct problems and emotional distress. Another meta-analysis study conducted by Taylor et al. (2017) reviewed 82 socialemotional learning programs found that 3.5 years after completion of the program, the benefits of SEL persisted. Another significant connection shared by Almlund, Duckworth, Heckman, \& Kautz (2011), the social-emotional competency is more predictive of academic and career achievement than IQ. In another study, students receiving the specified SEL intervention scored 13 points higher in academics, demonstrated a 6 percent increase in high school graduation rates, and an 11 percent increase in college attendance rates. The study also revealed additional longterm benefits beyond the standard academic measures. The SEL participants were less likely to have a clinical mental health disorder, to have ever been arrested or to be involved with the juvenile justice system and participants had lower rates of sexually transmitted infections and pregnancies (Taylor et al., 2017).

\section{Systemic Implementation of Social Emotional Learning}


As evidenced in the data above, well-implemented SEL programs and practices can have positive impacts on students' lives. SEL instruction and programming takes place both at the whole-school and classroom level and is delivered by multiple stakeholders within the school community (Weissberg et al., 2015), including school counselors (Velsor, 2009). Evidence indicates that high-quality implementation is positively associated with better student outcomes. Jones and Bouffard (2013) highlight the importance of effective implementation of socialemotional learning as well as moving from "programs to strategies" as a way of changing mindsets concerning the comprehensive implementation of SEL within a school district. While well-designed SEL programs implemented with fidelity have been associated with positive academic outcomes (Durlak et al., 2011), it is important to acknowledge that common barriers to program fidelity include sufficient dosage and accurate duration of program session (Jones, Brown, Hoglund, \& Aber, 2010). Other possible drawbacks of the SEL program model include having the sole focus be at the classroom level and facilitated within the classroom. Because of this hyper-focused classroom approach, SEL programs miss opportunities to help students develop SEL tools necessary for other environments, such as the playground, the lunchroom, and hallways. Finally, the other area impacting SEL programs centers on the fact that teachers receive little to no formalized training in SEL (Lopes, Mestre, Guil, Kremenitzer \& Salovey, 2012). Shifting from programs to strategies would provide a continuum of SEL approaches that range from routines, strategies, and structures educators and students can use daily and throughout the school to intensive services for students requiring the most support.

\section{Development of Indiana's Social-Emotional Learning Competencies}

CASEL's framework was the guide and foundation in building the Indiana SEL Competencies. Through the examination of 136 SEL frameworks, Berg et al. (2019) identified 
three key issues requiring additional attention a) the need to focus on SEL development across multiple sociocultural contexts (which can include students' complex identity development dependent on age, types of support, etc.), b) the explicit instruction and focus on cultural responsiveness, cultural/racial identity development, and developing a strength-based cultural lens for both adults and students, and c) intentional SEL strategies designed for students affected by trauma and chronic adversity.

Learning and responding to this work, two competencies were added: Sensory-Motor Integration competency and Mindset competency. Additionally, the remaining five Indiana SEL Competencies align with each of the five CASEL competencies. Yet, the Indiana SEL competencies have unique names setting them apart from the CASEL competencies as well as have distinct definitions. Although five of the Indiana SEL competencies articulate alignment with the CASEL standards, the Indiana competencies intentionally expand the work of CASEL by including neurodevelopmental, culturally and trauma responsive PK-12 indicators. In January 2019, the Indiana Social-Emotional Learning Competencies for students in grades Pre-K through 12, (Desautels \& Oliver, 2019) were released to address the social and emotional well-being through a neurodevelopmental, culturally responsive framework. The foundation for these competencies was developed from the fields of educational neuroscience research, socialemotional research, trauma, and culturally responsive best practices.

The Indiana SEL competency title, the definition, and the aligned CASEL competency (in parenthesis if applicable) are listed below.

1. Sensory-Motor Integration (new competency): the ability to have body awareness and recognize sensations in the body. Gaining sensory-motor integration is an important skill 
for managing transitions, changing routines, increasing alertness for learning, and improving regulation.

2. Insight (Self-Awareness): the ability to know your emotions and how they affect your thoughts and actions. Gaining insight is an important skill for building self-confidence, self-esteem, and empathy for others. Insight helps students recognize their own strengths and areas of growth.

3. Regulation (Self-Management): the ability to recognize and manage one's emotions. Regulation skills build positive self-control, positive self-discipline, and impulse control.

4. Collaboration (Relationship Skills): the ability to work well with others, including in the group and teamwork environment. Collaboration works to build positive communication and conflict management skills.

5. Connection (Social-Awareness): the ability to have strong social awareness, giving students the ability to take the perspectives of others and empathize with people of diverse backgrounds and cultures.

6. Critical Thinking (Responsible Decision-Making): the ability to make constructive choices and understand metacognitive strategies to enhance learning. Critical thinking skills build responsible decision-making, analytical, and critical inquiry skills which are necessary to approach learning from an innovative, creative, multicultural, and ethical lens.

7. Mindset (new competency): the ability to demonstrate cognitive flexibility and a willingness to learn. Developing mindset is a critical learning skill for building perseverance, adaptability, self-discovery, resilience, and the ability to receive and give constructive feedback. 


\section{Developing the Competencies and Framework}

Learning from the thorough research conducted by the Assessments Work Group Frameworks Subgroup (Dusenbury, Yoder, Dermody, Weissberg, 2019; Jones, Bailey, Brush, \& Nelson, 2019), the Indiana SEL Competencies sought to address the three recommendations identified as key factors contributing to healthy SEL development, a) to focus on SEL development across multiple sociocultural contexts, b) to focus on cultural responsiveness and cultural/racial identity development, and the explicit instruction to support a strength-based cultural lens for both adults and students, and c) to focus on the intentional SEL strategies designed for students affected by trauma and chronic adversity. The addition of the SensoryMotor Integration and Mindset competencies enhanced the focus on providing supports for students impacted by trauma, develop ongoing opportunities for strength-based multicultural competency development, and incorporate diverse SEL approaches using the most current neurodevelopmental research (Jones et al., 2019; Weissberg, 2019).

\section{Two new competencies.}

The Sensory-Motor Integration and Mindset competencies were created to address the barriers identified that most often contribute to inequitable access to social, emotional, academic development (SEAD), therefore impact overall student wellbeing and outcomes (Simmons, Brackett \& Adler, 2018). The educational neuroscience framework used in the development of the competencies provided multiple opportunities to address the equity issues previously identified.

Specifically, within the sensory-motor integration competency, educational neuroscience seeks to raise awareness of how biological factors play an important role in accounting for differences in learning ability between individuals, not only environmental (Royal Society, 
2011). Within trauma-responsive practices, when a student experiences chronic stress or fear, the survival part of the brain is activated, resulting in alerting the limbic system and the fight/flight/freeze response; the survival brain's activation decreases functioning of other brain areas responsible for information processing, planning, and other executive functions (Van der Kolk, 2014; Perry, 2017; Pawlo, Lorenzo, Eichert, \& Ellis, 2019). Students are unable to learn new information when they continuously operate in a fear response state because the brain, when affected by trauma or chronic stress, is significantly limited in its capacity to receive, integrate, and store new information; the toxic levels of stress hormones can interrupt typical physical and mental development and even change the brain's architecture (Sacks, \& Murphey, 2018). The sensory-motor integration competency focuses on the mind-body connection to help bring awareness to both students and educators in understanding how stress can have a profound impact on the body and brain's biochemistry (Sousa, 2010).

Educational neuroscience helped frame the mindset competency based on the concepts of neuroplasticity (Siegel, 2010) and growth mindset (Dweck, 2006). Siegel explained neuroplasticity as the brain's ability to change its structure in response to ongoing experience and focused practice. Through explicit instruction and focus on neuroplasticity, students are provided skills and strategies to build resiliency and new prosocial behavioral skills to respond to stress, challenges, or conflict. In doing so, the classroom environment becomes a place that is welcoming, supportive, and fosters resilience. Infusing growth mindset principles reinforces the brain's malleability and helps demonstrate that intelligence is not fixed (Dweck, 2006). Students' beliefs about intelligence are critical to not only their academic outcomes but also helping them develop resilience following life's adverse experiences (Yeager \& Dweck, 2012).

\section{Connecting the framework to strategic state priorities}


In Dusenbury's (2019) comprehensive state review of SEL standards/framework the most effective strategic priorities and approaches were connected to one or more of seven state drivers (Berg et al., 2017; Dusenbury, 2019). Indiana's framework has worked to align all seven drivers to build interprofessional and collaborative practices across systems. Two drivers, Workforce readiness, college and career readiness, and 21st-century skills and Multitiered systems of support (MTSS) are described to provide examples of how our framework has set out to intentionally link the new SEL Competencies with these high priority state initiatives. Appendix A provides the full list and description of the seven drivers.

\section{Workforce readiness, college and career readiness, and 21 st-century skills.}

Indiana Senate Enrolled Act 297 states that no later than July 1, 2019, each school within a school corporation shall include interdisciplinary employability skills standards established by the Indiana Department of Education (IDOE), in conjunction with the Department of Workforce Development, and approved by the State Board of Education, in the school's curriculum. IDOE created Indiana’s Employability Skills Standards (Indiana Department of Education (IDOE), 2019), which allow students to be prepared for the ever-changing needs of today's workforce. These standards were to be implemented beginning the 2019-2020 school year. The standards are based on the National Employability Skill Standards from the Office of Career, Technical, and Adult Education (OCTAE), the Indiana Department of Workforce Development's Employability Skills Benchmarks, the Governor's Work Ethic Certificate, and the Indiana Department of Education's Social-Emotional Learning Competencies. The standards are arranged within four key areas: Mindsets (M), Work Ethic (WE), Learning Strategies (LS), and Social and Emotional Skills (SE). 
During the initial stages of the Employability Skills Standards, social-emotional learning skills were identified as being a theme to be embedded within these standards. Another resource to further promote Indiana's SEL competencies has recently been developed and reinforce the connections between Employability Skills Standards, Indiana Social-Emotional Learning competencies, and the ASCA Mindsets. The crosswalk can be found in Appendix B.

\section{Multitiered systems of support (MTSS).}

A multi-tiered system of supports (MTSS) is a systemic, data-driven program, designed to address academic and behavioral concerns by employing a comprehensive, three-tiered level system of supports comprised of both prevention and intervention strategies (Sugai \& Horner, 2009). MTSS ensures a detailed and structured universal support system for students as well as providing individualized support options for those students with higher needs. The Indiana Department of Education selected MTSS as the primary structure for teaching and learning in our State ESSA plan based on many factors. Still, key among them was its ability to maximize equity, provide student/family access to necessary mental health resources, and ultimately, to positively impact student outcomes (Horner et al., 2010). With a record of demonstrated impact on school climate, safety, and increased student access to mental health resources, MTSS is the optimal vehicle for supporting our educational partners' attainment of academic, behavioral, and social-emotional goals (National Center on Response to Intervention 2010).

\section{Implications for School Counseling Practice}

Integrating SEL within the Deliver component of the American School Counselor Association National Model (American School Counselor Association (ASCA), 2018a) is a natural fit for the types of social-emotional, academic (Lemberger \& Hutchison, 2014), and career services provided by professional school counselors (American School Counselor 
Association (ASCA), 2019). As schools adopt SEL programs, teachers are often tasked with the implementation of all or parts of the student delivery component. According to the 2018 McGraw Hill Social and Emotional Learning Report, only 22 percent of teachers reported feeling "very prepared" to teach SEL. School counselors are equipped to provide training and ongoing consultation to support teacher SEL development (Cowan, Vaillancourt, Rossen, \& Pollitt, 2013; ASCA, 2019).

A one-size-fits-all approach does not work to meet the needs of all students, nor does it challenge equity, access, and social-emotional related issues for students who present with a continuum of needs ranging from sensory, impulsivity, and regulatory problems (Perry, 2017). A comprehensive school counseling program that aligns with a multitiered system of supports (MTSS) is integral in the process of removing these systemic barriers and working toward a strength-based, whole student focused-culture that supports the social-emotional, academic, and behavioral success for all students (ASCA, 2019).

Utilizing the Indiana SEL competencies as a foundation, school counselors can build lessons and programming to teach students about the important role their brains play in learning and life. For example, when concentrating on the sensory-motor integration competency, school counselors can help students build healthy stress response skills by first focusing on the mindbody connection (Stahl et al., 2015). By teaching strategies that include mindfulness practices, students will have opportunities to practice paying attention in the present moment as they begin to develop awareness of the experiences within the mind-body in relation to the thoughts and feelings they are experiencing. This example only highlights one SEL competency-based school counseling intervention. To note, school counselors do not have to work alone when teaching 
mindfulness. As teachers develop these skills, invite them to co-teach because they need to be modeling these skills for their students.

School counselors are at the frontlines of college and career readiness planning. With the crosswalk between the Indiana Employability Skills Standards and the Indiana SEL

Competencies, school counselors can easily articulate a clear connection between the knowledge and skills required for all students. This tool also helps counselors advocate for dedicated time to teach these competencies and justify why they are the right professional in the school to provide these services.

It is critical that school counselors work collaboratively to ensure universal SEL supports targeting the cognitive, social, emotional, behavioral, and ethical development of all students (Grant et al., 2017) be employed. The Indiana SEL Competencies have opened opportunities for continued partnerships and collaboration with school administrators and teachers. The Indiana Association of School Principals (IASP), a longtime partner and supporter of school counselors, named SEL as the topic in 2019 for their regional workshops across the state and a key theme at their 2019 annual conference. Being afforded the opportunity to present multiple times at these events, a strategic effort was made not only to build knowledge and awareness regarding SEL implementation but also to explicitly share how school counselors are vital partners in effective SEL implementation. While administrators may feel pressure to act quickly regarding SEL implementation, we caution a fast approach before first building SEL teacher skills.

Additionally, comprehensive SEL programs focus on increasing capacity-building, including providing support and services (both in-school and out-of-school) at tiers two and three. School counselors have the unique training, knowledge, and skillsets to provide support in all three tiers of SEL implementation. Finally, as we better understand the impact of traumatic 
experiences and employ universal screeners, school counselors can demonstrate their proficiency in the use of data data (Betters-Bubon, Brunner, \& Kansteiner, 2016) and work collaboratively with other educators in the building to ensure appropriate trauma and culturally responsive practices are delivered to all students.

Through the comprehensive and systemic SEL implementation, school counselors will have a platform to advocate not only for all students but also for the profession of school counseling. The ASCA National Model School points out the unique position school counselors hold to collaborate, consult, and partner with other educators, community partners, and families (ASCA, 2019). School counselors can serve as leaders in conversations about equity and social justice as it pertains to student behavior and success in schools. Through continued conversations, consultation (Pereza-Diltz, Moe, \& Mason, 2011), and targeted family involvement, school counselors can empower change and work towards equity for all. Table 1 provides sample roles and responsibilities that align with MTSS as well as strategies that support the implementation of the Indiana SEL competencies within a school district. The strategies are placed at the MTSS tiers, yet several strategies can span tiers. For example, consultation can span tiers two and three. Be creative and flexible as you think about integrating SEL strategies into the school counseling program. These strategies are only sample strategies that school counselors can explore with their administrator and advisory team, ensuring they fit within the scope and goals of the school counseling program and are not an exhaustive list.

Table 1.

School Counselor's Sample Roles within MTSS specific to Social Emotional Learning

\begin{tabular}{|c|c|c|c|c|c|}
\hline & Students & Teachers & Administrator(s) & Parents/Guardian & Community \\
\hline Tier 3 & $\begin{array}{l}\text { Individual } \\
\text { counseling; }\end{array}$ & & $\begin{array}{l}\text { Participate with } \\
\text { administrator in }\end{array}$ & $\begin{array}{l}\text { Provide outside } \\
\text { referral }\end{array}$ & $\begin{array}{l}\text { Oversee } \\
\text { community }\end{array}$ \\
\hline
\end{tabular}




\begin{tabular}{|c|c|c|c|c|c|}
\hline & $\begin{array}{l}\text { Functional } \\
\text { Behavior } \\
\text { Assessment or } \\
\text { other } \\
\text { assessment } \\
\text { tools to } \\
\text { support } \\
\text { student } \\
\text { success }\end{array}$ & & $\begin{array}{l}\text { discipline- } \\
\text { related } \\
\text { conferencing } \\
\text { (bringing SEL } \\
\text { perspective) }\end{array}$ & $\begin{array}{l}\text { resources as } \\
\text { appropriate }\end{array}$ & $\begin{array}{l}\text { partnerships } \\
\text { offering } \\
\text { services in } \\
\text { the } \\
\text { school/for } \\
\text { students; } \\
\text { Create and } \\
\text { update } \\
\text { community } \\
\text { referral } \\
\text { resource tool }\end{array}$ \\
\hline Tier 2 & $\begin{array}{l}\text { Check- } \\
\text { in/Check-out; } \\
\text { Small group } \\
\text { counseling to } \\
\text { support } \\
\text { specific SEL } \\
\text { skill } \\
\text { development; } \\
\text { Coordinate } \\
\text { mentor/mentee } \\
\text { program; } \\
\text { Coordinate } \\
\text { and supervise } \\
\text { peer } \\
\text { mediation/peer } \\
\text { helping } \\
\text { program }\end{array}$ & $\begin{array}{l}\text { Before/after- } \\
\text { school } \\
\text { programming } \\
\text { to support } \\
\text { educator } \\
\text { wellness } \\
\text { (i.e., } \\
\text { mindfulness, } \\
\text { self-care } \\
\text { group, etc.); } \\
\text { Provide } \\
\text { consultation } \\
\text { regarding } \\
\text { SEL support } \\
\text { (i.e., } \\
\text { classroom } \\
\text { management, } \\
\text { emotion } \\
\text { regulation, } \\
\text { etc.) }\end{array}$ & $\begin{array}{l}\text { Participate in } \\
\text { relevant } \\
\text { teaming to share } \\
\text { SEL perspective } \\
\text { to ensure SEL } \\
\text { continues to be } \\
\text { systemically } \\
\text { implemented; } \\
\text { Collaborate } \\
\text { with } \\
\text { administrator in } \\
\text { positive } \\
\text { discipline using } \\
\text { restorative } \\
\text { practices }\end{array}$ & $\begin{array}{l}\text { Provide } \\
\text { consultation } \\
\text { regarding SEL } \\
\text { support }\end{array}$ & $\begin{array}{l}\text { Oversee } \\
\text { community } \\
\text { partnerships } \\
\text { offering } \\
\text { services in } \\
\text { the } \\
\text { school/for } \\
\text { students; } \\
\text { Data } \\
\text { monitoring } \\
\text { for SEL } \\
\text { effectiveness } \\
\text { of } \\
\text { community } \\
\text { partnerships }\end{array}$ \\
\hline Tier 1 & $\begin{array}{l}\text { Classroom } \\
\text { lessons } \\
\text { supporting } \\
\text { SEL } \\
\text { development; } \\
\text { Facilitate } \\
\text { circle lessons; } \\
\text { Coordinate } \\
\text { schoolwide } \\
\text { advisory } \\
\text { program; } \\
\text { Support/teach } \\
\text { Indiana }\end{array}$ & $\begin{array}{l}\text { Co-teach } \\
\text { SEL lesson } \\
\text { with } \\
\text { teachers; } \\
\text { Provide } \\
\text { professional } \\
\text { development } \\
\text { to support } \\
\text { educator } \\
\text { self-care and } \\
\text { wellbeing; } \\
\text { Provide data } \\
\text { from needs } \\
\text { assessment }\end{array}$ & $\begin{array}{l}\text { Provide } \\
\text { professional } \\
\text { development } \\
\text { with } \\
\text { administrator on } \\
\text { SEL to whole } \\
\text { staff introducing } \\
\text { SEL and to } \\
\text { build educator } \\
\text { SEL knowledge } \\
\text { and skill } \\
\text { necessary for } \\
\text { implementation; } \\
\text { Review data }\end{array}$ & $\begin{array}{l}\text { Provide SEL } \\
\text { reinforcement } \\
\text { activities for at } \\
\text { home practice } \\
\text { (i.e., post on } \\
\text { website or send } \\
\text { in newsletter); } \\
\text { Coordinate an } \\
\text { SEL family } \\
\text { event }\end{array}$ & $\begin{array}{l}\text { Coordinate } \\
\text { community } \\
\text { advisory } \\
\text { groups; } \\
\text { Build } \\
\text { community } \\
\text { partnerships }\end{array}$ \\
\hline
\end{tabular}




\begin{tabular}{lll}
\hline Employability & or universal & from school \\
Standards & screening & climate survey \\
data to & for continuous \\
& educators & $\begin{array}{l}\text { improvement } \\
\text { cycle }\end{array}$ \\
\hline
\end{tabular}

\section{Summary and Next Steps}

The time is now to put the knowledge, research, and our continued insight about mental health and social-emotional learning into action. Building upon CASEL's foundational work in SEL, the Indiana SEL competencies have been created using educational neuroscience as a foundation to address the three recommendations (Dusenbury et al., 2019; Jones et al., 2019), identified as key factors contributing to healthy SEL development, a) to focus on SEL development across multiple sociocultural contexts, b) to focus on cultural responsiveness and cultural/racial identity development, and the explicit instruction to support a strength-based cultural lens for both adults and students, and c) to focus on the intentional SEL strategies designed for students affected by trauma and chronic adversity. The Indiana SEL Competencies have intentionally been connected to strategic state initiatives (i.e., employability skills and MTSS), and school counselors can leverage this alignment to further support the cognitive, social, emotional, behavioral, and ethical development for all students. Additionally, school counselors can provide consultation, professional development, and resources for educators and families to aide in their growth and development in the seven Indiana SEL competencies. Finally, an integral part of this work will continue to be outreach and advocacy to policymakers, both locally and nationally. An immense amount of work has been accomplished since the January 2019 release of the Indiana SEL Competencies. However, it is imperative that school counselors 'tell their story' to policymakers, both qualitatively and quantitatively (outcome data). School counselors need to use their training in leadership and advocacy to share outcome data 
with not only their school leaders but with legislators too. It is crucial to share how SEL benefits all students, as well as specific subgroups of students, illustrating the culturally responsive dimension of the SEL competencies. The Indiana SEL Competencies have provided an opportunity to shine a light on school counseling and the work school counselors are uniquely trained to provide within the school community. School counselors need to seize this opportunity, demonstrating their knowledge, skills, and leadership ability to implement SEL across the school community. Indiana's SEL Competencies and all resources connected to the competencies are accessible and available to all states. SEL is an organic fit as counselors build comprehensive school counseling programs.

Nationally, school counselors are encouraged to find strategic state or local initiatives to align with SEL. Next, it is important that school counseling programs can articulate their expertise both in SEL and the specified strategic initiative. Finally, school counselors need to seek opportunities to position themselves as leaders, advocates, and change agents within the framework of SEL. Regardless if you are an Indiana school counselor or in another state, the momentum of SEL continues to grow. Seize this time to ensure the profession of school counseling is at the center of SEL implementation. The ultimate goal of school counselors' work is ensuring all students receive a high-quality, strength-based, equitable education, so too is that of SEL. 


\section{References}

American School Counselor Association. (2018a). ASCA national model: A framework for school counseling programs (4th ed.). Alexandria, VA: Author.

American School Counselor Association. (2018b). Position Statement: The school counselor and multitiered system of supports. ASCA Position Statements. Retrieved from https://www.schoolcounselor.org/asca/media/asca/PositionStatements/PS_MTSS.pdf

Almlund, M., Duckworth, A., Heckman, J., \& Kautz, T. (2011). Personality psychology and economics. In E. A. Hanushek, S. Machin, \& L. Woessmann (Eds.), Handbook of the Economics of Education (pp. 1-181). Amsterdam, Netherlands: Elsevier.

Berg, J., Osher, D., Same, M. R., Nolan, E., Benson, D., \& Jacobs, N. (2017, December 18). Identifying, defining, and measuring social and emotional competencies. Washington, DC: American Institutes for Research. Retrieved from https://www.air.org/sites/default/files/downloads/report/Identifying-Defining-andMeasuring-Social-and-Emotional-Competencies-December-2017-rev.pdf

Berg, J., Nolan, E., Yoder, N., Osher, D., \& Mart, A. (2019). Social-emotional competencies in context: Using social-emotional learning frameworks to build educators' understanding. Establishing Practical Social-Emotional Competence Assessments Work Group: Collaborative for Academic, Social, and Emotional Learning. Retrieved from https://measuringsel.casel.org/wp-content/uploads/2019/02/Frameworks-C.2-.pdf

Betters-Bubon, J., Brunner, T., \& Kansteiner, A. (2016). Success for all? The role of the school counselor in creating and sustaining culturally responsive positive behavior interventions and supports programs. Professional Counselor, 6(3), 263-277. Retrieved 
from

$\underline{\text { http://search.ebscohost.com.ezproxy.butler.edu/login.aspx?direct=true\&AuthType=ip\&d }}$ $\underline{\mathrm{b}=\text { eric } \& \mathrm{AN}=\mathrm{EJ} 1115904 \& \text { site }=\text { ehost-live \&scope }=\text { site }}$

Blyth, D.A. (2018). SEL frameworks: Practical challenges and opportunities. Establishing Practical Social-Emotional Competence Assessments Work Group: Collaborative for Academic, Social, and Emotional Learning. Retrieved from https://measuringsel.casel.org/wp-content/uploads/2019/01/Frameworks-A.2-revised.pdf

Borowski, T. (2019). CASEL's framework for systemic social and emotional learning. Establishing Practical Social-Emotional Competence Assessments Work Group: Collaborative for Academic, Social, and Emotional Learning. Retrieved from https://measuringsel.casel.org/wp-content/uploads/2019/08/AWG-Framework-SeriesB.2.pdf

Collaborative for Academic, Social, and Emotional Learning (2013). CASEL schoolkit: A guide for implementing schoolwide academic, social, and emotional learning. Chicago, IL: Author.

Collaborative for Academic, Social, and Emotional Learning. (2015). Effective social and emotional learning programs: Middle and high school edition. Chicago, IL: Author. Collaborative for Academic, Social, and Emotional Learning. Casel.org. (2018). What is SEL?. [online] Retrieved from: https://casel.org/what-is-sel/\#

Collaborative for Academic, Social, and Emotional Learning. (2019). Indicators of schoolwide SEL. [online] Retrieved from https://schoolguide.casel.org/what-is-sel/indicators-of$\underline{\text { schoolwide-sel/ }}$ 
Cowan, K. C., Vaillancourt, K., Rossen, E., \& Pollitt, K. (2013). A framework for safe and successful schools [Brief]. Bethesda, MD: National Association of School Psychologists.

Desautels, L., Oliver, B. (2019). PK- 12 Social-emotional learning competencies: Built upon a neurodevelopmental culturally responsive framework. Indiana Department of Education. Retrieved from https://www.doe.in.gov/sites/default/files/sebw/sel-competencies-final.pdf

Durlak, J. A., Domitrovich, C. E., Weissberg, R. P., \& Gullotta, T. P. (Eds.). (2015). Handbook for social and emotional learning. New York, NY: Guilford.

Durlak, J. A., Weissberg, R. P., Dymnicki, A. B., Taylor, R. D. \& Schellinger, K. B. (2011). The impact of enhancing students' social and emotional learning: A meta-analysis of school-based universal interventions. Child Development, 82(1): 405-432. https://doi.org/10.1111/j.1467-8624.2010.01564.x

Dusenbury, L., Yoder,N., Dermody, C., Weissberg, R. (2019). An examination of frameworks for social and emotional learning (SEL) reflected in state K-12 learning standards. Establishing Practical Social-Emotional Competence Assessments Work Group: Collaborative for Academic, Social, and Emotional Learning. Retrieved from https://measuringsel.casel.org/wp-content/uploads/2019/02/Framework-C.3.pdf

Dweck, C.S. (2006). Mindset: The new psychology of success. New York: Random House. Elias, M. J. (2003). Academic and social emotional learning. International Academy of Education Educational Practices Series, H. J. Walberg (Ed.). Geneva, Switzerland: UNESCO, International Bureau of Education. 
Farmer, E. M., Burns, B. J., Philip, S. D., Angold, A., \& Costello, E. J. (2003). Pathways into and through mental health services for children and adolescents. Psychiatric Services, 54, $60-67$.

Grant, S., Hamilton, L. S., Wrabel, S. L., Gomez, C. J., Whitaker, A., Tamargo,...Ramos, A. (2017). Social and emotional learning interventions under the every student succeeds act. Santa Monica, CA: RAND Corporation.

Gonzalez, G. G. (1982). Progressive Education: A Marxist Interpretation (Vol. 8). Cincinnati, OH: Marxist Educational Press.

Horner, R. H., Sugai, G. M., \& Anderson, C. M. (2010). Examining the evidence base for school-wide positive behavior support. Focus on Exceptional Children, 42(8), 1-14. https://doi-org.ezproxy.butler.edu/10.17161/foec.v42i8.6906

Humphrey, N. (2013). Social and emotional learning: A critical appraisal. London, England: SAGE.

Immordino-Yang, M.H., Darling-Hammond, L., Krone., C. (2018). The brain basis for integrated social, emotional, and academic development: How emotions and social relationships drive learning. The Aspen Institute.

Indiana Department of Education. (2019). Indiana's employability skills standards. Retrieved from https://www.doe.in.gov/sites/default/files/wf-stem/employability-skillscompetencies-final.pdf

Jones, S., Bailey, R., Brush, K., \& Nelson, B. (2019). Introduction to the taxonomy project: Tools for selecting \& aligning SEL frameworks. Establishing Practical Social-Emotional Competence Assessments Work Group: Collaborative for Academic, Social, and 
Emotional Learning. Retrieved from https://measuringsel.casel.org/wpcontent/uploads/2019/02/Frameworks-C.1.pdf

Jones, S. M., \& Bouffard, S. M. (2012). Social and emotional learning in schools: From programs to strategies. Social Policy Report, 26 (4) 3-22. Society for Research in Child Development.

Jones, S. M., Brown, J. L., Hoglund, W., \& Aber, J.L. (2010). A school-randomized clinical trial of an integrated social-emotional learning and literacy intervention: Impacts after 1 school year. Journal of Consulting and Clinical Psychology, 78(6), 829-842. http://dx.doi.org.ezproxy.butler.edu/10.1037/a0021383

Jones, S. M., \& Kahn, J. (2017). The evidence base for how we learn: Supporting students' social emotional, and academic development. Consensus statements of evidence from the council of distinguished scientists. Washington, DC: National Commission on Social, Emotional, and Academic Development, The Aspen Institute. Retrieved from: https://www.aspeninstitute.org/publications/evidence-base-learn/

Kozlowski, K. A. (2013). Integrating school counseling core curriculum into academic curriculum. Journal of School Counseling, 11(5). Retrieved from http://search.ebscohost.com.ezproxy.butler.edu/login.aspx?direct=true\&AuthType=ip\&d $\underline{b}=$ eric $\& A N=E J 1012286 \&$ site $=$ ehost-live \&scope $=$ site

Lemberger, M. E., Hutchison, B. (2014). Advocating student-within-environment: A humanistic approach for therapists to animate social justice in the schools. Journal of Humanistic Psychology, 54, 28-44. http://doi:10.1177/0022167812469831 
Lopes, P. N., Mestre, J. M., Guil, R., Kremenitzer, J., \& Salovey, P. (2012). The role of knowledge and skills for managing emotions in adaptation to school: Social behavior and misconduct in the classroom. American Educational Research Journal, 49(4), 710-742. http://dx.doi.org.ezproxy.butler.edu/10.3102/0002831212443077

McGraw-Hill Education (2018). Social and emotional learning report. New York, NY: Author. Retrieved November 6, 2019 from https://s3.amazonaws.com/ecommerceprod.mheducation.com/unitas/corporate/promotions/2018-social-emotional-learningsurvey.pdf

Merikangas, K. R., He, J., Burstein, M., Swanson, S. A., Avenevoli, S., Cui, L., . . Swendsen, J. (2010). Lifetime prevalence of mental disorders in U.S. adolescents: Results from the National Comorbidity Survey Replication-Adolescent supplement. Journal of the American Academy of Child \& Adolescent Psychiatry, 49, 980-989

National Center on Response to Intervention. (2010). Essential components of RTI: A closer look at response to intervention. Washington, DC: U.S. Department of Education, Office of Special Education Programs.

National Institute of Mental Health. (n.d.). Any disorder among children. Retrieved January 16, 2015, from https://www.nimh.nih.gov/health/statistics/prevalence/any- disorderamongchildren.shtml

Osher, D., Kidron, Y., Brackett, M., Dymnicki, A., Jones, S., \& Weissberg, R. P. (2016). Advancing the science and practice of social and emotional learning: Looking back and moving forward. Review of Research in Education, 40(1), 644-681. 
Pawlo, E., Lorenzo, A., Eichert, B., and Ellis, M.J. (2019, Oct. 28). All SEL should be traumainformed. Phi Delta Kappan, 101 (3), 37-41.

Payne, P., Levine, P. A., \& Crane-Godreau, M. A. (2015). Somatic experiencing: using interoception and proprioception as core elements of trauma therapy. Frontiers In Psychology, 6, 93. https://doi-org.ezproxy.butler.edu/10.3389/fpsyg.2015.00093

Perera-Diltz, D. M., Moe, J. L., \& Mason, K. L. (2011). An exploratory study in school counselor consultation engagement. Journal of School Counseling, 9(13). Retrieved from http://search.ebscohost.com.ezproxy.butler.edu/login.aspx?direct=true\& AuthType $=$ ip\&d b=eric\&AN $=$ EJ933179\&site $=$ ehost-live\&scope $=$ site

Perry B. D. (2017). Trauma-and stressor-related disorders in infants, children and adolescents. In Beauchaine T. P. \& Hinshaw S. P., (Eds.)., Child and Adolescent Psychopathology, (683-705). New York, NY: Wiley.

Royal Society. (2011). Neuroscience: Implications for education and lifelong learning (Brain Waves Module 2). London: The Royal Society. Retrieved from royalsociety.org/uploadedFiles/Royal_Society_Content/policy/publications/2011/4294 975733.pdf

Sacks, V., \& Murphey, D. (2018). The prevalence of adverse childhood experiences, nationally, by state, and by race or ethnicity, Child Trends. Retrieved from https://www.childtrends.org/publications/prevalence-adverse-childhood-experiencesnationally-state-race-ethnicity

Siegel, D. (2011). Mindsight: The new science of personal transformation. Bantam Books: New York. 
Simmons, D. N., Brackett, M. A., \& Adler, N. (2018). Applying an equity lens to social, emotional, and academic development. Edna Bennett Pierce Prevention Research Center, Pennsylvania State University. Retrieved from https://dpi.wi.gov/sites/default/files/imce/sspw/pdf/SEL__Equity.pdf

Sklad, M., Diekstra, R., De Ritter, M., Ben, J., \& Gravesteijn, C. (2012). Effectiveness of schoolbased universal social, emotional, and behavioral programs. Do they enhance students' development in the area of skill, behavior, and adjustment? Psychology and Schools, 49, 892-909. https://doi-org.ezproxy.butler.edu/10.1002/pits.21641

Sousa, D. (2010). Mind Brain and Education; Implications for the classroom. Bloomingdale, IN: Solution Tree Press.

Stahl, J.E., Dossett, M.L., LaJoie, A.S., Denninger, J.W., Mehta, D.H., Goldman, R., ... Benson, H. (2015). Relaxation response and resiliency training and its effect on healthcare resource utilization. PLoS ONE 10(10): e0140212. https://doi.org/10.1371/journal.pone.0140212

Sugai, G., \& Horner, R. H. (2009). Responsiveness-to-intervention and school-wide positive behavior supports: Integration of multi-tiered system approaches. Exceptionality, 17, $223-237$.

Taylor, R., Oberle, E., Durlak, J.A., \& Weissberg, R.P. (2017). Promoting positive youth development through school-based social and emotional learning interventions: A metaanalysis of follow-up effects. Child Development, 88, 1156-1171. https://doiorg.ezproxy.butler.edu/10.1111/cdev.12864 
The Aspen Institute National Commission on Social, Emotional, and Academic Development (2017). Putting it all together: Curriculum that addresses the social and emotional dimensions of learning helps all students thrive academically and prepare for challenges beyond school. Retrieved from https://assets.aspeninstitute.org/content/uploads/2017/08/NCSEADCaseStudy1.pdf

Van der Kolk, B. (2014). The body keeps the score: Brain, mind, and body in the healing of trauma. New York, NY: Penguin Books.

Velsor, P. V. (2009). School counselors as social-emotional learning consultants: Where do we begin? Professional School Counseling, 13(1), 50-58. https://doiorg.ezproxy.butler.edu/10.5330/PSC.n.2010-13.50

Weissberg, R. P. (2019). Promoting the social and emotional learning of millions of school children, Perspectives on Psychological Science, 14(1) 65-69. https://doiorg.ezproxy.butler.edu/10.1177/1745691618817756

Weissberg, R. P., Durlak, J. A., Domitrovich, C. E., \& Gullotta, T.P. (2015). Social and emotional learning: Past, present, and future. In Durlak, J. A., Domitrovich, C. E., Weissberg, R. P. \& Gullotta, T. P. (Eds.), Handbook on social and emotional learning: Research and practice, (pp. 3-19). New York, NY: Guilford.

Wiglesworth, M., Lendrum, A., Oldfield, J., Scott, A., ten Bokkel, I., Tate, K., \& Emery, C. (2016). The impact of trial stage, developer involvement and international transferability on universal social and emotional learning programme outcomes: A metaanalysis. Cambridge Journal of Education, 46, 347-376. https://doiorg.ezproxy.butler.edu/10.1080/0305764X.2016.1195791 
Yeager, D. S., \& Dweck, C. S. (2012). Mindsets that promote resilience: When students believe that personal characteristics can be developed. Educational Psychologist, 47(4), 302-314. https://doi-org.ezproxy.butler.edu/10.1080/00461520.2012.722805 


\section{Appendix A}

\section{Connections to Strategic Priorities and Approaches}

- Academic Integration. SEL competencies are critical for successful engagement and execution in all learning. It is important to make these connections explicit to encourage educators to foster student SEL competencies that support academics.

- Mental health and well-being is foundational to social and emotional adjustment and competence. Trauma and other adverse childhood experiences (ACES) can negatively affect mental health as well as academic, social, and emotional development.

- Whole child is a coordinated approach to education and public health that works to ensure that each child will be "healthy, safe, engaged, supported, and challenged." We know from our work in the CSI that, thanks in part to ESSA, many states are organizing to reflect a whole child approach, as well as equity and cultural responsiveness, in their educational systems.

- Workforce readiness, college and career readiness, and 21st-century skills are closely aligned with SEL, because social and emotional skills (such as self-management, communication, goal setting, collaboration, and responsible decision-making) are all critical skills for success in college and career.

- School climate and culture refer to the quality as well as norms and values of the school environ- ment. School climate and culture are associated with student and teacher social and emotional well-being.

- Character education and development is a process designed to promote citizenship, civic principles and values, and ethical behavior. It aligns with social and emotional development. 
- Multitiered systems of support (MTSS) (formerly called response to intervention, or RTI) recognizes that academic and behavioral functioning are intertwined. MTSS is a systemic approach designed to identify and coordinate evidence-based interventions. MTSS can include positive behavioral interventions and supports (PBIS). SEL programs and approaches are often seen as an important component of universal approaches within MTSS, because they are designed to promote positive academic and behavioral outcomes in all students.

Available at https://measuringsel.casel.org/wp-content/uploads/2019/02/Framework-C.3.pdf 


\section{Appendix B}

\section{Employability Skills Standards (COMPETENCIES)}

\section{Introduction to Indiana's Employability Skills Standards}

Indiana's Employability Skills Standards allow students to be prepared for the ever-changing needs of today's workforce. These standards are to be implemented in the 2019-2020 school year. The expectation is for students to work through the standards in multi-subject areas. As students move through grade levels, they will work with and experience the standards at those grade bands (K-2, 3-5, 6-8, 9-10, and 11-12). The standards are based on the National Employability Skill Standards from the Office of Career, Technical, and Adult Education (OCTAE), the Indiana Department of Workforce Development's Employability Skills Benchmarks, the Governor's Work Ethic Certificate, and the Indiana Department of Education's Social-Emotional Learning Competencies. The standards are arranged within four key areas: Mindsets (M), Work Ethic (WE), Learning Strategies (LS), and Social and Emotional Skills (SE).

\begin{tabular}{|c|c|}
\hline Mindsets & Work Ethic \\
\hline Learning Strategies & Social and Emotional Skills \\
\hline
\end{tabular}

Mindsets (M) The established set of attitudes impacting self-growth.

\section{Lifelong Learning}

Demonstrate willingness to work and learn, and continually apply new knowledge.

\section{Self-Confidence}

Possess belief in own ability to succeed and assert self when necessary. 
Work Ethic (WE) A set of values centered on the importance of doing work and reflected especially in a desire or determination to work hard.

\section{Self Discipline}

Demonstrate self-control and behave in accordance with rules with minimal direction.

\section{Independence}

Successfully carry out expectations with minimal supervision.

\section{Perseverance}

Demonstrate endurance, and capacity to complete tasks.

\section{Time Management and Organization}

Plan and organize long and short-term goals while understanding how to balance school, home, and community activities.

\section{Adaptability}

Manage transitions and adjust to changing situations and responsibilities.

\section{Integrity}

Act in a trustworthy and honest manner.

\section{Professionalism}

Demonstrate skills and behaviors appropriate for school and work environments.

Learning Strategies (LS) Processes and tactics students employ to aid in the cognitive work of thinking, remembering or learning.

\section{Effective Communication}

Apply skills to clearly, effectively, and convincingly express ideas and messages to others appropriate to the environment.

\section{Aptitude Awareness}

Identify and communicate individual interests and skills that align related coursework and experiences to potential career paths and to in-demand occupations.

\section{Decision-Making}

Utilize critical thinking skills and perspectives of others to make informed decisions based on options, rewards, risks, limits, and goals.

\section{Initiative}

Apply self-motivation and self-direction to work and learning.

\section{Attention to Detail}

Achieve thoroughness and accuracy when accomplishing a task. 


\section{Problem Solving}

Apply critical and creative thinking skills to resolve problems.

Social and Emotional Skills (SE) The process through which the knowledge, the attitudes, and the skills necessary to understand and manage emotions, set and achieve positive goals, feel and show empathy for others, establish and maintain positive relationships, and make responsible decisions is acquired.

\section{Regulation}

Recognize and manage one's emotions.

\section{Connection}

Demonstrate the ability to network with others through social awareness and cultural sensitivity.

\section{Collaboration}

Work well with others in a team.

Available at https:/www.doe.in.gov/sites/default/files/wf-stem/employability-skillscompetencies-final.pdf 